\title{
The Image of Indian Women in the Novels of Gita Hariharan
}

\author{
S. Mubeena Tabassum, R. Manjula \\ JNTUA College of Engineering Anantapur Andhra Pradesh 515002, India
}

\section{ABSTRACT}

Many feminist writers have fought for the freedom of women from the bondage of man. Gita hariharan was one among them. She has been acclaimed as one of the prominent women writers who had contributed to Indian literature feminist and social ideals. She was the winner of the Common Wealth Writers' prize for her first Novel "The Thousand Faces of Night”. Being an Indian woman, she deals with the themes of feminist components, socio political issues in her novels. She portrays real life characters of Indian women who had been victims of gender exploitation. She portrays the predicament of Indian women caught between tradition and modernity and their emergence as individual women. She makes us to realize inferior and subordinate position of woman in family and society. She also claims for rightful, equal and independent status that would act as impetus to her development as an individual and in society. Main objective of this article is to highlight the predicament of Indian women with reference to the novel "The Thousand Faces of Night

KEY WORDS: FEMINISM, WOMEN, IMAGE, TRADITION, SUFFERING, SOCIETY.

\section{INTRODUCTION}

The novel originated in the early 18th century after the Italian word 'Novela' which was used for stories in the medieval period. Its identity has evolved and it is now considered to mean a work of prose fiction over 50,000 words, Novels focus on character development more than the plot. The father of English novels in the history of English literature is 'Henry Fieldings', But R.K. Narayana and Raja Raoare considered to be the pioneers of IndianEnglish fiction.

The First Indian English novel was 'Raj Mohan's wife' by Bankin Chandra Chattarjee, in 1935. Subsequently Indian writers were appreciably encouraged when the 'Board of Bengal' Rabindranath Tagore, was awarded the Nobel Prize in Literature in the year 1913 for the novel Gitanjali. Consequently numerous Indian English novels began appearing Historical Fiction and myth constitutes a large portion of their canon. Mythology in Indian context is perhaps the most utilized and most admired for every generation and genre. India is having an umbrella of civilization with great tradition and heritage. The ethnicity of this country is prolific with a lot of myths.

Biosc Biotech Res Comm P-ISSN: 0974-6455 E-ISSN: 2321-4007

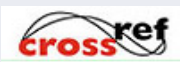

Identifiers and Pagination

Year: 2021 Vol: 14 No (8) Special Issue

Pages: 01-05

This is an open access article under Creative

Commons License Attribn 4.0 Intl (CC-BY). DOI: $h t t p: / / d x . d o i . o r g / 10.21786 / b b r c / 14.8 .1$
It has produced great epics of the world, i.e. Ramayana and Mahabharata which invariably preach the principles of life to the people. Indian English writers are influenced by the Myths carried on from ancient time thus trying to preserve the culture heritage and religious beliefs.

Gita Hariharan was born in Coimbatore, India and she grew up in Bombay and Monila. She was educated in these two cities and later in the United States. She got a Bachelor of Arts(Honours) degree in English Literature and Psychology from Bombay University in 1974; and a master of Arts in Communications From The Graduate School of Corporate and Political Communication Fairfield University. Connecticut 1977. She Worked as a staff writer in WNET channel 13 in New York and from 1979 to 1984 , She worked as an editor in the Mumbai, Chennai and New Delhi offices of Orient Longman, where she was responsible for the social science, fiction and women's studies lists from 1985 to 2005, she worked as a freelance professional editor for a range of academic institutions and foundations. She is at present a writer based in New Delhi. In 1995, Hariharan challenged the Hindu Minority and Guardianship Act as discriminatory against Women. The Case, Gita Hariharan and Another Vs. Reserve Bank of India and Another, led to a supreme court Judgment in 1999 on guardianship.

She has a name to reckon with particularly in the context of postcolonial Indian Writings. A Writer as well as a social activist. Gita Hariharan's Novels successfully represent the traditional values ofIndian society integrated with modern thinking and consciousness. Herfirst novel 'The

\section{Article Information}

Received: 05 ${ }^{\text {th }}$ May 2021 ccepted after revision: $25^{\text {th }}$ June 2021 
Thousand Faces of Night (1992) won the common wealth writer's prize in 1993. This was followed by the Ghost of Vasumaster(1994), when Dreams Travel (1999), In time of Siege (2003) and Fugitive Histories(2009). She has also authored a collection of Short Stories.The Art of Dying (1993), The winning Team (2004), Asouthern Harvest (1993), and Sorry Best Friend!(2004). She also wrote number of news papers articles and columns. Her style of writing is different from other writers. The quest for identity and self respect is an important theme in Gita Harihan's novels.

In all the novels of her, Gita Hariharan deals with the themes of social, political issues. Her novels focus on feminist components. Nevertheless, She portrays the marginalize Females in Indian Sociey " The Thousand Faces of Night”(1992) is Gita Hariharan's Maiden novel for which she was awarded the common wealth writers prize (1993) and with this award she has marked her indelible presence in the realm of Indian English Fiction. She while portraying the lives of three different generations of Indian women dexterously interweaves the stories of these women with the stories of same other prominent women of Indian Mythology. She felt heart for those who are still struggling to overcome from their own destiny by demanding a life of equality and liberty in a male dominated society. Hariharan once proclaimed that the children should also get mother's name after their name. She raised an objection on the manhood that in the present society women's position is deteriorating. Gita Hariharan's novel 'The Thousand Faces of Night' depicts the three woman characters- Devi, Sita and Mayamma. Devi is theprotoganist in this novel on which the whole story revolves. Sita the mother of Devi married at 20, living a settled life. Mayamma also got married at an early age. She was a cook and caretaker in that particular house in which Devi is living.Mayyamma tried to overcome from the grievances of her life, though her husband is drunkyard. She manages the married life. As Gita Hariharan belongs to a traditional Hindu family, well acquainted with all the myths and she perfectly blends the myth and reality in modern Indian life.

Devi, who is playing a vital role in the novel, is simple, lucid and flat charactered girl. She was pursuinga degree in America. She was maintaining one boy friend whose name was 'Dann'. He was a black person (negro), loved Devi very much. As 'Dann' wanted to marry Devi, once he invited Devi to his house. He introduces her to his family. His family members also liked Devi very much despite of their different culture and traditions. But Devi was surprised to see their appreciation upon her. Inspite of all these lovable moments which she was spent along with 'Dann' and his family members. She left USA and returned her home country India only on the request of her mother sita. The novel shows the strengthen blood relations and theirworthy deeds. "Once the word is put forth, it must be kept even after, all the obstacles they are facing on the way", i.e. an Indian Culture.So, she respected the Indian Culture and she returned India to fullfil the dreams of her mother upon her, by leaving 'Dann' alone in USA. Her mother sita is having some responsibilities on her shoulders after the demise of her father. Sita the mother of Devi wanted to get married Devi with the bridegroom of her own choice. At this juncture Devi fails neither to take a rebellious action against her mother, for getting marry her with a strange person nor she could become a beloved of her boy friend'Dann'. This happens only for the sake of the Indian culture and tradition.

Indian mothers trained and protect their daughters by giving their guidance and emotional support. In this novel the mother sita, interwoven the dreams of marriage of Devi by her own choice. So she conducted swayamwara for her daughter and she made it easy to choose. In swayamwara scene Gita Hariharan shows the Hindu Mythology, in which Devi recollected her grandmother's storiesregarding Mahabarata. Nala the brave, handsome and virtuous king came to take part in swayamwara and won the hand of Damaynthi. In the Same manner Devi also established the concept of swayamvara. Here also Devi accepts the man as her husband, who was the choice of her mother and she determined to continue her life. The another comparison was in Mahabharata, Gandhari married a rich prince called Drudarastrudu and accepted her destiny by bounding her eyes with the help of a veil, saying that when her husband is unable to see the beauty of a wonderful place why should she do so.

Hariharan, who wrote a straight forward manner, succeeded in picturising various concepts like woman hood, individuality etc. and also in describing the relevance of these concepts in modern Indian society. Her novels present the efforts of patriarchy on women from different social classes and ages, particularly the varied responses to the restrictive institution of marriage, especially in the 'The Thousand Faces of Night' It evokes characters from the mythology and lives of saints and relates them to the characters in the novel. Gita Hariharan has made feminism through various symbols. She has mentioned that the concept of lives of females must be made up of 'live and let others live'. Hariharan's novel is quote driven, as her acknowledgments recommend as she thanks the writers of works. Hariharan's novel 'The Ghost of VasuMastr is actually about well being on all the levels; that of the soul, the brain, as well as the body. Vasu master's actual physical ailments get some attention, while a few would like him to go along with the road to enlightenment a swan has after that there's Vasumaster's father, a physician of the really smart and understanding sort, who shows an assortment of ways of healing.

Hariharan depicted the sacrificing nature of traditional women through the character of mangla 'The Ghost of Vasu Master'. But in the same novel she has given another face of woman by portraying vasu master's grandmother. Though she was an uneducated lady she was able to judge masters objectively and she didn't obey her husband blindly. She was dare enough to mock at his mistakes. In 'The Ghost of Vasu Master' the author depicts three main characters Vasu's mother lakshmi, wife mangala and the grandmother. His wife mangala and mother Lakshmi 
were exhibited like carbon copy of traditional woman. (H.B. Patil1) Gita Hariharan's novels focus on feminist elements and the 'The Ghosts of Vasu Master' is not the exception to this. However, the feminine ghosts include his mother, grandmother and the actress Rita mona is boyhood fancy. Vasu Master's mother diedwhen he was still a small kid. Her parents didn't give aname for almost one year because they donot want to spent money on her naming ceremony. Because she was a girl child that too born second in number when their first baby was also a daughter . They also feared that people would point out them for not giving birth to a son. The old woman sweeper of their of their own house once said that the girl would be the Laxmi of her husband's house. In this way she got the name Laxmi. But to the end of her life. She remained the sixth daughter of female in her life. She could never get over her inferiority complex. Gita Hariharan is critical of theconstraints of domestic life dominating patriarchy.

Patriarchy is a unique character of traditional Indian Society, which is reflected continuously from ancient to modern period. The male domination in a society not only creates women's life miserable but also it disturbs their peace and harmony. In the novel 'The Ghosts of Vasu Master' the protagonist was 'vasu master' who was an English teacher, was highly influenced by old age traditions and customs in our society. He was found and brought up in a rigid social system and he never touched by the progressive winds. The behavior of vasu master has been depicted in an effective manner. His relationship with his wife Mangala and other female characters show his secondary attitude to look at women. The male domination in an old age social structure is reshaped by author through the character of vasu master and the story is webbed around him. The socio cultural realities have been exposed properly. The Ghost of Vasu Master is a narration which reflects the patriarchal system and the rebel of women in this system. The close observation of tradition and protect against it, is an important feature of Hariharan's novel 'The Ghost of Vasu Master'. The literature is social entity has been evolved by writer, by making a clear distinction between age old traditions and revolt against them. The sociological study of GitaHariharan's novels shows that she had made a painstaking analysis of social reality through her novel.

'The Ghost of Vasu Master' is the novel begins with the retirement of the protagonist Vasu Master, a recently retired teacher from P.G. Boys School, situated in a small town. Elipetti in India. He was a teacher of English Literature and Language for nearly forty years. The beginning of the novel can be considered as an experimental in the sense that generally the novels begins with the birth of the protagonist but this novel begins with the final stage of a life i.e. vasu master's retirement. The main important point is that vasu master taught the same class nearly for forty years but still he fails to find out the psyche of the students. He suffers from the feelings of nostalgia and is in search of self-identity. He wakes up to find himself dead as he depicts his condition through the lives of Franz Kafka, who says, "A man didn't know that he existed, until one day he awoke to find himself dead"(24). However his retirement turns out to be a new beginning for him that paves the way to know and understand himself. Vasu master begins to recollects incidents from the past and discovers, in his own unique way, the nature of teaching, teacher and student. The task related to teaching mani that he takes up after his retirement becomes a process of exploration of his own self.

As a man too, he seems to be a failure as he fails to maintain the relations and balance in his own life. Vasu starts teaching mani to fulfill the emptiness, loneliness after retirement and to restore his title of 'Vasu Master' in the real sense. Vasu seeks mani as his only companion, who can provide him past in words and the theoretical possibilities of future. Vasu feels that it's the time for which he has been waiting all these years, for a new beginning. Finally the situation of Vasu master and Mani is shown almost equal and parallel in the novel as both suffer one from identity crisis and other from his problematic mind. Since then the Psychological journey of vasu master begins along with the teaching of Mani. A long suppression in the hands of male chanvinistic society, an immense suffering in the male hypocrites, a continuous predicament from the four walls, has forced the woman to revolt against the traditional customs and beliefs with the rise of feminism. The educated women started producing a body of women literature with new styles and new techniques. Their writings highlighted the physical and mental agony of women that awaken many a women to fight for their identity, dignity and respect. Ramuuniyal expresses her opinion thus:

“Contemporary women's fiction is a challenge to master narratives. At a manifest level, it is an attempt to read life and rewrite the notion of subjectivity within the parameters of 'difference'. It focuseson 'differences that make a difference' to women in a dominant masculine culture". Such ideas encouraged women writers to reveal the pathetic condition of woman, instead of the other themes. Anita Desai, ShashiDeshpande, Arundhati Ray, Kiran Desai etc.,along with Gita Hariharan are some of the feminist writers who attack the traditional and cultural notions with humour, subtleties and tenderness through their wirtings. Gita Hariharan has occupied a significant place among the post modern Indian English women novelists as a different story teller. The protagonists of her novels are constantly trying to break the silence ofsuffering.

Hariharan's novel 'When Dreams Travel' centers aroundShahrzad and Dunyazad, two Valiant sisters and shahryar and shahzaman two brothers. It reveals the continous killing of the thousands of brides in the hands of a powerful battle through her witty stories to survive more than thousand nights. After a thousand nights, shahrzad survives herself as well as others. However, after some time the news of shahrzad's sudden death makes her sister. Dunyazad to retreat the place of shahrayar in Shahabad. Thus, theentire novel 
revolves around Dunyazad's journey to find out the reason behind her sister's unexpected deathMaltiSingh says that: " GitaHariharan's when Dreams Travel is an evocative and outstanding novel. She illustrates the war of sexes through this novel and emergence of new-fangled identities and the power of women's wit through thecharacters of shahrzad, Dunyazad and Dilshad" Because of the queen's infidelity shahzaman stabs his queen and the sultan of Samarkand orders the execution of his wife.

Then he conspires with his brother and started marrying a virgin every night and kills her after his lust of contentment. This new policy creates a panic in the kingdom. One day the daughter of wazirshahrzadcamefarward to marry sultan shahryar with an intention of saving the girlhood of that kingdom. She became sultan shahryar's wife with a hidden scheme to save her and others she weaves a new story each night she tells a story to king leaving it incomplete and promising to finish it the following night. The stories are very interesting so the king is eager to hear the end that he puts off her implementation from day to day and finally abandons his cruel plan. This story telling continues for a thousand and one nights after which the sultan is cured of his obsession against women.

From the perception of Hariharan we can say that she intends to show us the hatred of man on woman and the way they are fulfilling their lust by deflowering the virgin girl in the Arab Anthologies. Hariharan explores the war of the sexes with powerful multivoiced narrative. A magical tour deforce by a writer at the height of her powers, 'When Dreams Travel' weaves round Scheherazade or shahrzad of the thousand and one nights a vibrant, Inventive story about that old game that's never played out: the quest for love and power. The novel 'In Times of Siege' is her fourth novel. This novel treats as Hariharan's personal because in the 1995. She tried to open an account in the Reserve Bank of India for her son who was eleven years old. But she fails in opening an account because it needs her husband's signature.This was based on Hindu law, that a woman has the guardianship right only after the death of her husband. This was not linked by Hariharan. So, along with her husband she filed a case in Supreme Court against the Hindu law. Finally, she won the case and it was in favor of women. The Indian Court changed the law in 1999 that a mother is undoubtedly a child's natural guardian.This paves the way for Hariharan to write this novel, named 'In Times of Siege'.

In this novel the protagonist was a middle aged history professor in kasturba Gandhi University (KGU). His name was Shirmurthyhis wife was Rekha and She has gone to USA to meet her daughter Tara. Meena was the another important person who was the daughter of shivamurthy's childhood friend once she got an accident, in that, her leg was fractured. So, she is staying in shivmurthys house. Meenawas a sociology student in Kamala Nehru University.Meena's presence has brought shiv's room a new look. She was the woman who were affected by antisikhriots after Indira Gandhi's assassination in 1984.
Being an 'activist', she frequently attends meetings and talks of causes and street theatre, gender and invites arrest with the ease of a veteran. Meanwhile, the professor of HistoryShivmurthy is caught up in a controversy over his lesson on 12thcentury poet and social reformer Basava. Since it hurts the sentiments of the Hindu watchdog group 'IthihassurkshaManch' they find fault with shiv for his intentional distortion of Indian medieval history and demand an apology for that. Following meena'sadvice, the professor neither apologizes nor withdraws his lesson. Here we can see the shadow of author Gita Hariharan in the character of Activist Meena. Hariharan is very much active in human rights activities. She is the one who challenged the Hindu Minority and Guardianship Act as discriminatory against women in 1995.

The case, Gita Hariharan and another vs. Reserve Bank of India led to a Supreme Court Judgment in 1999 on guardianship. Meena also works for the women who were affected in anti sikh riots. She frequently attends meetings and talks of causes and street theatre, gender and invites arrest with the ease of a veteran as Hariharan in real life. Finally from the above instances we articulate the verbal attack and its severity on author's ideological opponents. The plot, the write-up and the style used in the novel, altogether present a never ending ideological war between the characters. Hariharan, the author of the above four novels, is skilled enough to portrays the characters in a simple and lucid manner. Hariharan's fictional characters grow as they progress from positions to vulnerability to relative strength. They achieve psychological and individual wholeness. When they are able to fight oppression, whether its source is in the cultural or traditional or societal roles assigned to them.

\section{REFERENCES}

Gita hariharans's -'The Thousand Faces of Night' www. pengin.co.in ISBN978-0-140-12843-7

Hariharan Gita The Ghosts of Vasu Mater. New Delhi: Penguin Books Ltd., 1994276 print

In Times of Siege.India; Penguin Books. 2004 Print Nityanandam, Indira "A Search for Identity" Gita Hariharan's - The Thousand Faces of Night Indian women Novelists. Ed. R.L. Dhawan, New Delhi; prestige Books, 1995

PandeyMiti "Feminism in contemporary British and Indian English Fiction” sarupand;sons, New Delhi, 2010, 26 print

Roshni, C, “Re-reading Gita Hariharan's when Dreams Travel; A Feminist Approach”, International Journal of English Language, Literature and Humanities. Vol7 Issue 2, February 2019:736-743.

Singh, Malti, "Tradition and Modernity: Changing Images of Woman in the Novels of ManjuKapur and Gita Hariharan; A comparative study" Ph.D Thesis 2015. https://shodhganga. Inflibnet.ac.in/ handle/10603/70315? mode=Full. 
Sunita, Sinha "Revisioning Myths, Dreams and History:

A Feminist Reading of Gita

The Ghost of Vasu Master, India, Penguin Books 1994

Print
UniyalRamu“ Rewriting Culture: Contemporary Indian woman's Fiction” Feminism and Recent Indian Literature(Vol.1) ed by R.K. Dhawan. New Delhi; prestige Books. 2008.56 